\title{
Using a systematic approach and theoretical framework to design a curriculum for the Shaping Healthy Choices Program
}

This manuscript is intended for the Research Briefs section of the Journal of Nutrition Education and Behavior.

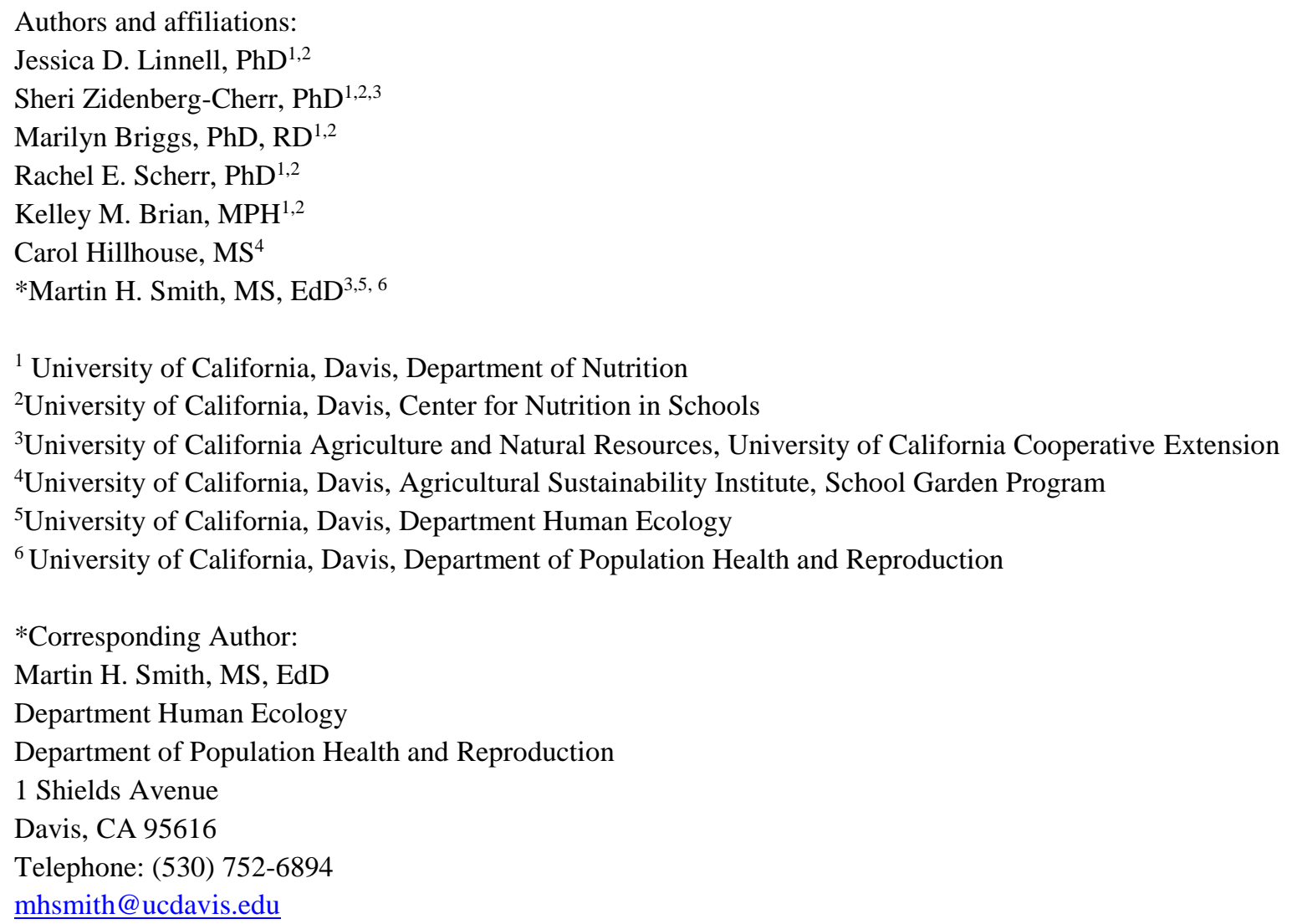

\section{Acknowledgments}

The authors want to recognizethe undergraduate students who participated in the development of Discovering Healthy Choices: Kelly Ho, HeeJoo “Kristi” Kim, Hillary Lawson, Erica Oberg, Ally Sy, Michelle Wong, Noel Zeng, and Courtney Zimmerman. Additionally, the authors wish to thank the participating Child Development Centers and their students. Funding for this study was provided by University of California Agriculture and Natural Resources Competitive Grant \#11-1018, United States Department of Agriculture Training Grant 2011-3842020082, and Henry J. Jastro Graduate Research Award 2012-2013. 


\section{INTRODUCTION}

Dietary behaviors among children in the United States represent a major public health concern. Recent data show that a high percentage of children are consuming inadequate amounts of nutrient-rich foods like fruits and vegetables and many do not meet the recommended amounts of some nutrients, including calcium, vitamin D, fiber, and potassium. ${ }^{1,2}$ Another area of concern is the continuing high prevalence of obesity among children and adolescents. ${ }^{3}$

In order to maximize the potential to improve children's dietary behaviors, experts recommend that school-based nutrition education interventions use multi-component strategies that address several levels of social organization concomitantly (e.g., individual, school, family, community). ${ }^{4}$ Nutrition interventions are thought to be most effective in preventing childhood obesity when they combine classroom education with environmental changes, incorporate nutrition and physical activity, and promote parental and community involvement. ${ }^{5}$ Greater improvements in nutrition- and health-related behaviors are demonstrated in programs that integrate theoretical models of dietary behavior. ${ }^{6}$ In addition, controlled trials in school-based programs utilizing nutrition curricula enhanced by garden activities have demonstrated greater improvements in nutrition knowledge, consumption of vegetables, preferences for vegetables, and willingness to taste vegetables, compared to those without. ${ }^{7-11}$

The Shaping Healthy Choices Program (SHCP) was developed to investigate the effectiveness of a multi-component, school-based nutrition intervention. The objectives were to: increase upper-elementary aged children's nutrition knowledge and use of reasoning skills; promote availability, consumption, and enjoyment of fruits and vegetables; improve dietary patterns; encourage physical activity; foster positive changes in the school environment; and 
facilitate development of an infrastructure to sustain the program. ${ }^{12}$ These objectives were to be accomplished through nutrition education in the classroom, increased access to fresh fruits and vegetables in the school cafeteria, dissemination of family newsletters, expanding community partnerships, and the formation of school-site wellness committees.

A prerequisite to meeting these objectives was the development of a curriculum for upper-elementary aged students that integrated behavior theory and included garden-enhanced activities. Though several publications have cited positive nutrition-related outcomes of gardenenhanced nutrition interventions among upper-elementary children, the specific processes by which curricula used in these programs were developed have not been described in detail. ${ }^{7-9,13-15}$ Illustrative of this, descriptions of the curricula typically include a summary of main topics, duration, frequency and quantity of activities, objectives, behavior theory, gardening activities (i.e., maintenance and harvest), and vegetables grown, but there is minimal discussion concerning the specific approaches used to develop the curricula; without understanding such processes used, replication is difficult. ${ }^{7-9,13-15}$

In support of the need for research literature describing specific curriculum development approaches, a review of garden-based nutrition education interventions concluded that future publications should provide more information about the intervention development and implementation in order to fully understand variations in student outcomes between programs. ${ }^{16}$ The purpose of the current article is to address this gap in the literature and describe the systematic, intentional processes used in the development of the curriculum for SHCP.

\section{METHODS}


The goal of the curriculum development process for SHCP was to design a sequence of learning experiences for upper-elementary aged children to gain nutrition knowledge and advance their reasoning skills so they could make evidence-based decisions about their diets. To accomplish this, four researchers with expertise in the areas of nutrition science, nutrition education, inquiry-based education, curriculum development, and garden-based learning formed a curriculum design team. In addition, eight undergraduate students majoring in nutrition science and clinical nutrition were recruited as volunteer interns. Researchers and undergraduate students worked together to develop and pilot test activities with upper elementary-aged students.

The undergraduate students were each assigned the development of one curriculum module. Specifically, they were to develop two activities within each module: one classroom activity and a second activity designed for implementation in an instructional garden. The role of the researchers was to work closely with the undergraduate students in the development process by providing guidance, recommendations, and edits to curriculum activities. The contributions of the researchers ensured activities met curriculum objectives, addressed educational standards, supported theoretical constructs, and were sequenced to build knowledge and skills over time.

The curriculum design team met weekly for nine months. These one-hour meetings were facilitated by the researcher with expertise in curriculum development and were structured so that team members participated in reflective practice. Specifically, team members presented current iterations of activities and engaged in discussions on challenges and successes experienced during curriculum development, pilot-testing, and revisions of activities. ${ }^{17}$ 
Before the curriculum development process began, researchers identified the Social Cognitive Theory (SCT) and constructivism as the theoretical underpinnings for the curriculum activities. ${ }^{18,19}$ The primary SCT constructs chosen for the curriculum were behavioral capability, reciprocal determinism, and self-efficacy. ${ }^{18}$ Inquiry-based education and experiential learning, educational approaches rooted in constructivism, were the pedagogical strategies selected. ${ }^{20,21}$

\section{Curriculum Development Using Backward Design}

The approach used to develop the curriculum was Backward Design. ${ }^{22}$ This three-step process involves the identification of learning objectives, determination of acceptable evidence of learning, and design of activities to directly align with learning objectives and selected evidence of learning.

Applying the first step of Backward Design, specific learning objectives for the curriculum were selected within three key domains: dietary recommendations, nutrition concepts, and critical thinking skills. Additionally, three overarching content areas were identified: introducing agricultural practices, supporting health through diet and physical activity, and using reliable resources to make dietary choices. Dietary recommendations identified for inclusion were based on the Dietary Guidelines for Americans 2010 (DGA) and MyPlate. ${ }^{23,24}$ Specific nutrition concepts were identified from Nutrition to Grow On, an existing evidence-based, garden-enhanced nutrition curriculum that has been used by other researchers when developing nutrition education interventions. ${ }^{7,9,25}$ Specific grade-level standards for the curriculum were identified to integrate relevant standards-based learning objectives. Standards addressed included: California Nutrition Education Competencies; Common Core State Standards for Mathematics and English Language Arts; and Next Generation Science Standards. ${ }^{26-28}$ 
The design team then organized the learning objectives into activity modules based on nutrition concepts identified. An emphasis was placed on vertical organization, sequencing modules to provide opportunities to build knowledge and skills over time, and horizontal organization, connecting activities to real-world situations and the broader goals of SHCP. ${ }^{29}$

Following the second step of Backward Design, curriculum design team members identified acceptable evidence of learning through the use of authentic assessment strategies. Authentic assessment involves real-world tasks that allow students to exhibit their understanding of knowledge and skills while engaged in an activity (e.g., performance of a task; response to a prompt) as opposed to a test or quiz at the end of a lesson.

In the third step of Backward Design, activities were designed so that they were directly aligned with identified learning objectives and provided opportunities for pre-determined evidence of learning. Curriculum activities were developed using guided inquiry organized explicitly around a five-step Experiential Learning Cycle with the following phases: Experience, Share, Process, Generalize, and Apply. ${ }^{20,21}$ Additionally, activities were designed to help students advance metacognitive abilities through the use of open-ended prompts to describe their thinking processes during the Share, Process, and Generalize phases of the Learning Cycle. ${ }^{21}$ Each module included one classroom activity, one garden-based activity, at least one take-home activity, and a goal-setting activity. Each of the undergraduate students was responsible for developing activities within one module with guidance from the research team members. Classroom activities were developed first, followed by the development of garden, take-home, and goal-setting activities.

\section{Curriculum Refinement through Pilot-Testing}


The curriculum was pilot-tested with upper-elementary-aged school children (grades 4-6) and occurred in two phases. During Phase 1, individual activities were implemented with 30 children enrolled at two Child Development Center (CDC) sites in Davis, California. The purpose of this phase of pilot-testing was to conduct a trial of individual activities among learners in the intended age group and to ascertain whether children would be capable of understanding the intended concepts, as demonstrated by the pre-determined evidence of learning (Table 1). Observational data were collected for formative purposes and were recorded using a plus/delta sheet, a tool designed to help identify what is going well and what needs to be changed. ${ }^{29}$ The observation sheet had prompts representing the themes of data to record: effectiveness of procedures, developmental appropriateness, suitability of student groupings, level of student interest and engagement, efficacy of the materials, and activity duration in order to guide data collection. A researcher on the design team and the individual facilitating the activity completed the observation sheet and compared observations to achieve agreement. Subsequently, curriculum design team members met and discussed formative data collected and potential revisions to address problematic procedures and materials. Subsequently, activities were amended as necessary. If a majority of children exhibited evidence of learning then the procedures were not revised.

In Phase 2 of pilot testing, the amended activities were implemented fully in sequence. Implementation occurred four days per week over a four-week period with 10 upper elementaryaged children at one CDC site. The CDC site chosen approximated a formal classroom setting; a container garden was established to allow pilot-testing of the garden-enhanced activities. Observational data collected during this phase placed an emphasis on vertical and horizontal 
organization of the curriculum. ${ }^{25}$ The structured observation process described in Phase 1 was also used in Phase 2. Curriculum design team members discussed data collected; further modifications to activities were made as needed. A diagram of the curriculum development and pilot-testing processes is depicted in Figure 1. The cost for phases I and II of pilot testing was approximately $\$ 400$, which included copies of activity handouts and supplies, and garden materials.

In discussions with the University of California, Davis Human Subjects Institutional Review Board it was concluded that the development and pilot testing of the curriculum did not qualify as human subjects' research and thus was exempt from review.

\section{RESULTS}

Outcomes from this investigation included learning objectives, evidence of learning, activities, and data-driven revisions of the curriculum based on pilot-test data. The resulting curriculum is entitled Discovering Healthy Choices.

\section{Identification of Learning Objectives}

Specific nutrition concepts were identified as learning objectives in the first step of Backward Design and are presented in Table 1. These objectives included: agriculture and geography; physical activity and the human circulatory system; physiological roles of nutrients; 
measurements and serving size; MyPlate recommendations; nutrition facts labels; consumerism; and choosing healthy foods.

The curriculum design team then determined the sequence in which the nutrition concepts would be organized (Table 1). Additional learning objectives included dietary recommendations and critical thinking skills. Dietary recommendations chosen comprised key consumer messages from DGA and focused on foods suggested for increased consumption (e.g., whole grains, fruits, vegetables, and low-fat and non-fat dairy products). Reasoning skills identified for Discovering Healthy Choices included observing, classifying, ordering, measuring, making inferences, and predicting. $^{36}$

\section{Determination of Evidence of Learning}

Acceptable evidence of learning identified as part of the curriculum development process is shown in Table 1. Specifically, curriculum design team members determined ways in which students would demonstrate understanding using authentic assessment strategies. Examples included: students will construct a daily meal plan that follows MyPlate recommendations; students will demonstrate number of servings within a portion; and students will identify consumer advertising strategies.

\section{Development of Activities}

The activities developed by the curriculum design team in the third and final step of Backward Design are described in Table 2. Classroom activities were designed for students to develop behavioral capability by building foundational knowledge and skills, to promote selfefficacy through opportunities to apply that knowledge and those skills in garden activities, and 
to influence reciprocal determination by having students engage with their families through takehome activities in the home environment. The garden activities developed for Discovering Healthy Choices placed an emphasis on learning experiences where students work in teams to select, plant, maintain, and harvest their own herbs and vegetables.

The activities were designed to directly align with SHCP objectives. To increase knowledge and reasoning skills, activities were developed using Backward Design, utilized experiential and inquiry-based learning strategies, and were organized sequentially so understanding could be developed over time..$^{19-22,29}$ To increase the likelihood of increased consumption and enjoyment of vegetables, garden activities and opportunities to taste vegetables

were included. $^{7-11}$ To encourage physical activity, a module was designed around this objective and was also addressed in the module that focuses on MyPlate recommendations.

\section{Curriculum Revisions through Pilot Testing}

Formative data collected during pilot testing of Discovering Healthy Choices were used to improve activity design. Analysis of observations resulted in clarification of instructions, revisions in wording needed for developmental-appropriateness, and the creation or modification of handouts and worksheets. Specific examples of observations and subsequent revisions in Phases 1 and 2 are presented in Table 3.

Data from pilot-testing also provided the curriculum design team information on student misconceptions that interfered with learning intended concepts and signaled the need for activity modifications. For example, in pilot testing of Module 4 students misunderstood that "serving size" and "recommended amount" were conceptually equivalent. This could result in misunderstanding of MyPlate recommendations and the Nutrition Facts Label in subsequent 
activities, the activity was revised to better clarify that serving sizes are standardized reference amounts.

The result of the development effort was the Discovering Healthy Choices curriculum that includes 15, one-hour classroom and garden activities, and 19 take-home and goal-setting activities. $^{32}$ A formal evaluation of the effects of Discovering Healthy Choices on student learning and dietary behaviors as part of SHCP was conducted in a randomized controlled intervention during the 2012-2013 academic year among fourth-grade children. The results of this evaluation will be provided in a subsequent paper. The methods used for the above evaluation have been reported elsewhere. ${ }^{12}$

\section{DISCUSSION}

The Backward Design method provided researchers a systematic approach to develop curriculum activities that were grounded in a theoretical framework, included focused learning objectives, and provided opportunities for educators to observe learning outcomes using authentic assessment strategies. The Backward Design approach was chosen because it is logical, pragmatic, and provides a design template that is easy to follow. ${ }^{22}$ Additionally, it was selected because it was developed for designing experiential learning opportunities, which was consistent with education strategy identified for the curriculum.

Backward Design is a curriculum development strategy that is structured to identify

learning objectives and assessment strategies prior to developing activities. ${ }^{22}$ Utilizing this method provided researchers on this project a process and structure to develop a comprehensive, garden-enhanced nutrition curriculum. This approach also allowed the curriculum design team 
to develop a sequence of modules that built knowledge and skills over time, helping to ensure the SCT construct of behavioral capability was well supported. By identifying learning objectives and ascertaining the sequence of nutrition concepts in the first step of Backward Design, design team members were able to determine what conceptual understanding students would need to develop before subsequent, more complex material could be introduced. ${ }^{22}$ For example, in order to understand MyPlate recommendations in cup- and ounce-equivalents, students would need to be able to understand volumetric and weight measurements. As a result, the design team integrated the learning objective of using measurement tools into Module 4, which precedes MyPlate in Module 5.

It was also important to examine current nutrition recommendations and education standards to identify those that were relevant to the goals of SHCP. Integrating recommendations from DGA 2010 and MyPlate ensured that the nutrition messages were consistent with federal nutritional guidance. Reviewing education standards was critical to develop activities that were grade-level appropriate. For example, according to Next Generation Science Standards, 4th-grade students are expected to understand macrostructures in the body such as organs and systems. ${ }^{28}$ As a result, nutrients were described as having functions that could be understood at an organ or system level (e.g., calcium supports bone health, and vitamin A supports vision). In addition, the integration of education standards and current nutrition recommendations helps teachers address the challenges involved in meeting mandated subject area requirements while integrating nutrition into their classrooms. ${ }^{33-35}$ The curriculum design team identified these education standards as intended learning objectives in the first step of Backward Design to ensure that the standards would be fully integrated within the activities. 
To help support the SCT construct of behavioral capability specifically, reasoning skills were addressed, which are relevant to the goals of SHCP and nutrition education more broadly. Critical thinking skills enhance individuals' abilities to analyze and evaluate dietary information in order to make healthful food choices. For example: understanding how to classify foods into different groups helps students understand MyPlate recommendations; utilizing measurement tools like measuring cups and tablespoons allows for comprehension of serving amounts listed on food labels; and observing and comparing are required to make healthy food choices based on nutrients listed on food labels. In addition, activities that include prompts for metacognition may strengthen children's dietary decision-making skills by encouraging them to consider how they approach solving nutrition-related problems and apply dietary recommendations.

The determination of evidence of learning in the second step of Backward Design helped the design team maintain focus on developing activities that targeted intended learning objectives and included authentic assessment opportunities to ensure those objectives could be met. Authentic assessments allow educators to monitor the acquisition of knowledge and skills through students' performance during an activity as opposed to using a quiz or test after the completion of a lesson. ${ }^{22}$ This provides educators opportunities to make necessary adjustments in the facilitation of an activity to help students who may be having difficulty understanding intended concepts and avoid the development of misconceptions.

Weekly meetings by the curriculum design team to engage in discussion and reflective practice were valuable to the development process. Meetings provided a forum for team members to work collaboratively to design and revise activities. ${ }^{17}$ In addition, these meetings provided an opportunity to identify potential connections between activities to reinforce vertical organization. ${ }^{30}$ The curriculum design team recognized this iterative process as critical to the 
resulting Discovering Healthy Choices curriculum and recommend this approach for use in future curriculum development efforts.

Phase 1 pilot testing was necessary to collect formative data on individual activities. It provided an opportunity to assess if students could achieve intended learning objectives and ensure that activity procedures were written clearly and accurately so they could be carried out as intended before SHCP could be formally evaluated. Phase 2 pilot testing allowed the design team to observe the continuity of activities when implemented sequentially. Observational data helped the curriculum design team examine whether activities were connected conceptually, as well as linked with other components of SHCP.

The SCT construct of behavioral capability was integrated within all activities so that learners could: engage actively in the development of knowledge about nutrition concepts and dietary recommendations; advance their reasoning skills by making observations; record data; and draw inferences based on information they collect. Reciprocal determinism was addressed through activities intended to be carried out at home in real-world contexts. Take-home activities also included goal-setting and self-monitoring tasks to promote self-efficacy in using new knowledge and skills to make healthy choices.

Through the use of constructivist learning strategies, Discovering Healthy Choices activities were designed so that students engage in hands-on, inquiry-based activities where they can develop new knowledge, and challenge existing understanding of nutrition-related concepts. These learning strategies help advance metacognition through: direct experiences that build upon one another over extended periods of time; including opportunities for dialogue with other learners; and promoting problem-solving skills and self-reflection. ${ }^{15,36,37}$ Subsequently, new 
knowledge and skills are applied in authentic contexts through garden-and take-home activities that provide opportunities for learners to develop a deeper understanding of subject matter.

\section{CONCLUSION AND IMPLICATIONS}

Using a systematic approach to curriculum development provided the design team with a structure that allowed for thoughtful, intentional curriculum design. Specifically, this method resulted in curriculum activities with focused learning objectives and opportunities to determine evidence of student understanding. Furthermore, activities were grounded in a theoretical framework and were well-connected to overall SHCP goals.

The importance of using a research-based approach in the development of nutrition curricula was demonstrated during this investigation. Using qualitative methods to assess curriculum procedures and materials among children in the intended age-group provided information to inform the curriculum development and revision processes that would not have been otherwise ascertained. Randomized controlled trials are the gold standard for testing nutrition curricula, but are costly and time consuming. Before a curriculum can be tested in a randomized controlled intervention, researchers must be able to recognize whether the curriculum has the potential to effect change. Key components in this curriculum development process include: using an iterative approach, reflective practice, and weekly team meetings. Additionally, curriculum development requires the use of effective pedagogical strategies, understanding the intended learners, and knowledge of the context where the curriculum will be used. Lastly, conducting pilot testing before implementing a curriculum in a randomized 
controlled intervention provides validation that activity procedures are understandable and that students are able to learn the curriculum concepts and skills as intended.

The process used in curriculum development may be central to developing curricula that can help reduce the risk of obesity and improve consumption of nutrient-rich foods such as fruits and vegetables. Within the broader context of school-based nutrition programs, a recent metaanalysis concluded that such interventions have not been effective in reducing obesity, further stating that the identification of successful strategies was difficult due to limited published information about how programs were developed and implemented. ${ }^{38}$ Differences between curriculum design approaches may be an underlying factor that affects student outcomes. Consequently, thorough descriptions of the processes by which nutrition curricula are designed, and how theory and pedagogy are applied, should be presented in publications so that effective approaches to program development can be determined. Without this, the development of effective programs may be difficult to replicate and student outcomes may not be fully understood. 


\section{REFERENCES}

1. Guenther PM, Dodd KW, Reedy J, Krebs-Smith SM. Most Americans eat much less than recommended amounts of fruits and vegetables. J Amer Diet Assoc. 2006;106(9):1371-1379.

2. Krebs-Smith SM, Guenther PM, Subar AF, Kirkpatrick SI, Dodd KW. Americans do not meet federal dietary recommendations. J Nutr. 2010;140(10):1832-1838.

3. Ogden, C L, Carroll MD, Flegal KM, et al. Prevalence of childhood and adult obesity in the United States, 2011-2012. J Am Med Assoc.2014;311(8):806-14.

4. Briggs M, Fleischhacker S, Mueller CG. Position of the American Dietetic Association, School Nutrition Association, and Society for Nutrition Education: comprehensive school nutrition services. J Nutr Educ Behav. 2010;42(6):360-371.

5. Hoelscher DM, Kirk S, Ritchie L, Cunningham-Sabo L. Position of the Academy of Nutrition and Dietetics: interventions for the prevention and treatment of pediatric overweight and obesity. J Am Nutr Diet. 2013;113(10):1375-1394.

6. Contento I. Review of nutrition education research in the Journal of Nutrition Education and Behavior, 1998 to 2007. J Nutr Educ Behav. 2008;40(6):331-340.

7. Morris JL, Zidenberg-Cherr S. Garden-enhanced nutrition curriculum improves fourth-grade school children's knowledge of nutrition and preferences for some vegetables. J Am Diet Assoc. 2002;102(1):91-93.

8. McAleese JD, Rankin LL. Garden-based nutrition education affects fruit and vegetable consumption in sixth-grade adolescents. J Amer Diet Assoc. 2007;107(4):662-665. 
9. Morgan PJ, Warren JM, Lubans DR, Saunders KL, Quick GI, Collins CE. The impact of nutrition education with and without a school garden on knowledge, vegetable intake and preferences and quality of school life among primary-school students. Public Health Nutr. 2010;13(11):1931-1940.

10. Parmer SM, Salisbury-Glennon J, Shannon D, Struempler B. School gardens: an experiential learning approach for a nutrition education program to increase fruit and vegetable knowledge, preference, and consumption among second-grade students. J Nutr Educ Behav. 2009;41(3):212-217.

11. Ratcliffe MM, Merrigan KA, Rogers BL, Goldberg JP. The effects of school garden experiences on middle school-aged students' knowledge, attitudes, and behaviors associated with vegetable consumption. Health Promot Practice. 2011;12(1):36-43.

12. Scherr RE, Linnell JD, Smith MH, et al. Development and implementation methodologies of a multi-component, school-based nutrition education intervention. J Nutr Educ Behav. 2014;46(6):e13-21.

13. Heim S, Stang J, Ireland M. A garden pilot project enhances fruit and vegetable consumption among children. J Am Diet Assoc. 2009;109(7):1220-1226.

14. Lineberger SE, Zajicek JM. School gardens: can a hands-on teaching tool affect students' attitudes and behaviors regarding fruit and vegetables. Hort Tech. 2000;10:593-597

15. Jaenke RL, Collins CE, Morgam PJ, Lubans DR, Saunders KL, Warren JM. The impact of a school garden and cooking program on boys' and girls' fruit and vegetable preferences, taste rating, and intake. Health Educ Behav. 2012;29(2)131-141.

16. Robinson-O'Brien R, Story M, Heim S. Impact of garden-based youth nutrition intervention programs: a review. J Am Diet Assoc. 2009;109(2):273-280. 
17. Schön DA. The Reflective Practitioner; How Professionals Think in Action. New York, NY: Basic Books; 1983.

18. Glanz BKR, Viswanath, K. Health Behavior and Health Education: Theory, Research, and Practice. 4th ed. San Francisco, CA: Jossey-Bass; 2008.

19. Fosnot CT. Constructivism: theory, perspectives, and practice. New York, NY: Teachers College Press; 2005.

20. Colburn A. An Inquiry Primer. Science Scope. 2000; 23(6)42-44.

21. Kolb DA. Experiential Learning: Experience as the Source of Learning and Development. Englewood Cliffs, NJ: Prentice-Hall; 1984.

22. Wiggins G, McTighe J. Understanding by Design. Alexandria, VA: Association for Supervision and Curriculum Development, 1998.

23. United States Department of Health and Human Services, United States Department of Agriculture, United States Dietary Guidelines Advisory Committee. Dietary Guidelines for Americans, 2010. 7th ed. Washington, DC: Government Printing Office; 2010.

24. United States Department of Agriculture. MyPlate. www.choosemyplate.gov. Accessed August 14, 2014.

25. Morris JL, Koumjian KL, Briggs M, Zidenberg-Cherr S. Nutrition to grow on: a gardenenhanced nutrition education curriculum for upper-elementary schoolchildren. J Nutr Educ Behav. 2002;34(3):175-176.

26. California Department of Education. Nutrition Education Resource Guide for California Public Schools Grades Kindergarten through Twelve. In: Division NS, ed2011:148.

27. National Governors Association Center of Best Practices and Council of Chief State School Officers. Common Core State Standards. Washington, DC: Authors; 2010. 
28. NGSS Lead States. Next Generation Science Standards: for States, by States. Washington, DC: National Academies Press; 2013.

29. Helminski L, Koberna S. Total quality in instruction: A systems approach. H. V. Roberts (Ed.), Academic initiatives in total quality for higher education. Milwaukee, WI: ASQC Quality Press, 1995.

30. Tyler RW. Basic Principles of Curriculum and Instruction. Chicago, IL: University of Chicago; 1949.

31. Bransford J, National Research Council (U.S.), Committee on Developments in the Science of Learning, National Research Council (U.S.), Committee on Learning Research and Educational Practice. How People Learn: Brain, Mind, Experience, and School. Expanded ed. Washington, DC: National Academy Press; 2000.

32. Linnell JD, Smith, MH, Zidenberg-Cherr S. Discovering Healthy Choices. Davis, California: University of California, Davis; 2014.

33. Stang J, Story M, Kalina B. Nutrition Education in Minnesota Public Schools: Perceptions and Practices of Teachers. J Nutr Educ. 1998;30(6):396-404.

34. Graham H, Zidenberg-Cherr S. California teachers perceive school gardens as an effective nutritional tool to promote healthful eating habits. J Am Diet Assoc. 2005;105(11):1797-1800.

35. Jones AM, Zidenberg-Cherr S. Exploring Nutrition Education Resources and Barriers, and Nutrition Knowledge in Teachers in California. J Nutr Educ Behav. 2014;47(2):162-169.

36. Dewey J. Experience and Education. New York, NY: The Macmillan Company; 1938.

37. Vygotsky LS, Cole M. Mind in Society: the Development of Higher Psychological Processes. Cambridge, MA: Harvard University Press; 1978. 
38. Hung LS, Tidwell DK, Hall ME, Lee ML, Briley CA, Hunt BP. A meta-analysis of schoolbased obesity prevention programs demonstrates limited efficacy of decreasing childhood obesity. Nutr Res. 2015;35(3): 229-240. 


\begin{tabular}{|c|c|c|}
\hline Concept & $\begin{array}{l}\text { Evidence of Learning (Students will be able } \\
\text { to...) }\end{array}$ & $\begin{array}{l}\text { Module } \\
\text { Sequence }\end{array}$ \\
\hline $\begin{array}{l}\text { Food grown around the world } \\
\text { varies due to agricultural practices } \\
\text { and climate }\end{array}$ & $\begin{array}{l}\text { Describe that there are similarities of foods } \\
\text { grown where there are similar climates }\end{array}$ & 1 \\
\hline $\begin{array}{l}\text { Foods people eat vary due to } \\
\text { cultural traditions }\end{array}$ & $\begin{array}{l}\text { Describe different cultural foods and traditions } \\
\text { from various countries }\end{array}$ & 1 \\
\hline Function of the lungs and heart & $\begin{array}{l}\text { Explain that the heart pumps blood around the } \\
\text { body and the lungs are the point of gas exchange } \\
\text { between oxygen and carbon dioxide }\end{array}$ & 2 \\
\hline $\begin{array}{l}\text { Physical activities differ by } \\
\text { intensity }\end{array}$ & $\begin{array}{l}\text { Draw a graph of their heart and breathing rates at } \\
\text { different intensities and observe the differences }\end{array}$ & 2 \\
\hline $\begin{array}{l}\text { Different food groups have similar } \\
\text { types of nutrients }\end{array}$ & $\begin{array}{l}\text { Discuss similar characteristics between foods } \\
\text { with similar nutrients after categorizing them }\end{array}$ & 3 \\
\hline Biological roles of nutrients & $\begin{array}{l}\text { Students will be able to describe the specific } \\
\text { biological function of selected macronutrients } \\
\text { and micronutrients }\end{array}$ & 3 \\
\hline $\begin{array}{l}\text { Foods are measured using cups, } \\
\text { tablespoons, teaspoons, ounces, } \\
\text { and grams }\end{array}$ & $\begin{array}{l}\text { Demonstrate usage of appropriate measuring } \\
\text { tools for different foods (i.e., tablespoons for } \\
\text { small amounts, cups for large amounts) }\end{array}$ & 4 \\
\hline $\begin{array}{l}\text { Serving size is a standardized } \\
\text { reference amount }\end{array}$ & $\begin{array}{l}\text { Solve a mathematical problem to demonstrate } \\
\text { the number of servings within one portion }\end{array}$ & 4 \\
\hline $\begin{array}{l}\text { MyPlate Recommendations } \\
\text { provides information about daily } \\
\text { dietary needs }\end{array}$ & $\begin{array}{l}\text { Construct a daily meal plan based on MyPlate } \\
\text { Recommendations }\end{array}$ & 5 \\
\hline $\begin{array}{l}\text { Nutritional requirements vary by } \\
\text { life stage, gender, and physical } \\
\text { activity }\end{array}$ & $\begin{array}{l}\text { Describe differences between daily meal plans } \\
\text { for people with a variety of age, genders, and } \\
\text { physical activity levels }\end{array}$ & 5 \\
\hline $\begin{array}{l}\text { Nutrition Facts Labels is a source } \\
\text { of information about nutrient } \\
\text { content in food items }\end{array}$ & $\begin{array}{l}\text { Discuss the information on a food label that } \\
\text { helped them make a healthy choice }\end{array}$ & 6 \\
\hline $\begin{array}{l}\text { Food companies use strategies like } \\
\text { catchy jingles, free toys, sale } \\
\text { prices, and celebrity spokespeople } \\
\text { to influence food choices }\end{array}$ & $\begin{array}{l}\text { Act out a commercial that employs strategies } \\
\text { that food companies use. }\end{array}$ & 7 \\
\hline $\begin{array}{l}\text { Reliable information can be used to } \\
\text { choose healthy snacks }\end{array}$ & $\begin{array}{l}\text { Demonstrate the use of Nutrition Facts Labels } \\
\text { and MyPlate recommendations in the assembly } \\
\text { of a healthy snack }\end{array}$ & 8 \\
\hline
\end{tabular}


Table 2. Summary of Discovering Healthy Choices Activities

\begin{tabular}{|c|c|c|c|c|c|}
\hline & Module & Application of Social Cognitive Theory & Classroom Activity & Garden-Enhanced Activity & Take-Home Activities \\
\hline 1 & $\begin{array}{l}\text { Introduction to } \\
\text { Nutrition, Agriculture, } \\
\text { and Garden }\end{array}$ & $\begin{array}{l}\text { Behavioral capability: generate interest in } \\
\text { foods from around the world to encourage } \\
\text { cooking and eating new foods }\end{array}$ & $\begin{array}{l}\text { Explore agricultural practices from } \\
\text { around the world }\end{array}$ & $\begin{array}{l}\text { Grow vegetables from } \\
\text { countries investigated }\end{array}$ & $\begin{array}{l}\text { Explore cultural traditions and } \\
\text { cook recipes from countries } \\
\text { investigated }\end{array}$ \\
\hline 2 & $\begin{array}{l}\text { Getting Physically } \\
\text { Active }\end{array}$ & $\begin{array}{l}\text { Behavioral capability: developan } \\
\text { understanding of the importance of } \\
\text { physical activity to support a healthy } \\
\text { circulatory system and increase physical } \\
\text { activity } \\
\text { Reciprocal determinism: activity at home } \\
\text { with family to foster increased physical } \\
\text { activity among family members }\end{array}$ & $\begin{array}{l}\text { Explore the circulatory system } \\
\text { including gas exchange at the lungs } \\
\text { and the function of the heart. }\end{array}$ & $\begin{array}{l}\text { Observe differences in heart } \\
\text { rate and breathing rate during } \\
\text { resting and physical activity } \\
\text { while gardening to understand } \\
\text { differences between intensity } \\
\text { levels }\end{array}$ & $\begin{array}{l}\text { Observe differences in heart } \\
\text { and breathing rates when } \\
\text { getting physically active with } \\
\text { family members } \\
\text { Set goals for physical activity }\end{array}$ \\
\hline 3 & Nutrients We Need & $\begin{array}{l}\text { Behavioral capability: acquire knowledge } \\
\text { about nutrients present in different foods to } \\
\text { encourage consumption of a variety of } \\
\text { foods }\end{array}$ & $\begin{array}{l}\text { Investigate foods that provide } \\
\text { different nutrients and roles that } \\
\text { nutrients play in maintaining health }\end{array}$ & $\begin{array}{l}\text { Investigate the different } \\
\text { nutrients provided by } \\
\text { vegetables in the garden }\end{array}$ & $\begin{array}{l}\text { Explore a market to find out } \\
\text { where different foods come } \\
\text { from } \\
\text { Set goals to eat foods with a } \\
\text { variety of nutrients }\end{array}$ \\
\hline 4 & Food Math & $\begin{array}{l}\text { Behavioral capability: develop knowledge } \\
\text { and skills in using volumetric } \\
\text { measurements so that food labels and } \\
\text { MyPlaterecommendations can be } \\
\text { understood and used }\end{array}$ & $\begin{array}{l}\text { Examine instruments used for } \\
\text { measuring food and calculate the } \\
\text { servings in a portion }\end{array}$ & $\begin{array}{l}\text { Estimate number of servings in } \\
\text { different vegetables }\end{array}$ & $\begin{array}{l}\text { Observe serving sizes of } \\
\text { foods at home }\end{array}$ \\
\hline 5 & MyPlate & $\begin{array}{l}\text { Behavioral capability: acquire knowledge to } \\
\text { understand and apply recommendations to } \\
\text { meal planning } \\
\text { Self-efficacy: practice creating daily meal } \\
\text { plans according toMyPlate } \\
\text { recommendations }\end{array}$ & $\begin{array}{l}\text { Explore how MyPlate } \\
\text { recommendations vary by age, } \\
\text { gender, and physical activity level }\end{array}$ & $\begin{array}{l}\text { Explore MyPlate vegetable } \\
\text { subcategories using the five } \\
\text { senses }\end{array}$ & $\begin{array}{l}\text { Create a day's worth of meals } \\
\text { that meet the MyPlate } \\
\text { recommendations } \\
\text { Grow a home garden with } \\
\text { vegetables from MyPlate } \\
\text { subcategories } \\
\text { Set goals to meet MyPlate } \\
\text { recommendations }\end{array}$ \\
\hline 6 & Food Labels & $\begin{array}{l}\text { Behavioral capability: develop skillof } \\
\text { comparison and use knowledge of nutrients } \\
\text { to make choices using Nutrition Facts } \\
\text { labels } \\
\text { Reciprocal determinism: explore food } \\
\text { labels with family member to encourage } \\
\text { discussion about food choices in grocery } \\
\text { store environment }\end{array}$ & $\begin{array}{l}\text { Inspect Nutrition Facts labels and } \\
\text { use the information determine which } \\
\text { are the healthiest choices }\end{array}$ & $\begin{array}{l}\text { Construct Nutrition Facts } \\
\text { labels for the vegetables } \\
\text { growing in the garden by } \\
\text { collecting information about } \\
\text { nutrient contents }\end{array}$ & $\begin{array}{l}\text { Explore food labels at the } \\
\text { grocery store } \\
\text { Set goals to use Nutrition } \\
\text { Facts Labels }\end{array}$ \\
\hline 7 & Consumerism & $\begin{array}{l}\text { Behavioral capability: become aware of } \\
\text { food advertising strategies and emphasis } \\
\text { on using reliable information instead of } \\
\text { reaction to marketing techniques }\end{array}$ & $\begin{array}{l}\text { Identify strategies that food } \\
\text { companies use to influence dietary } \\
\text { choices }\end{array}$ & $\begin{array}{l}\text { Investigate how plants } \\
\text { "advertise" to pollinators }\end{array}$ & $\begin{array}{l}\text { Identify techniques food } \\
\text { companies use in television } \\
\text { ads to persuade consumers } \\
\text { Set goals to make informed } \\
\text { choices }\end{array}$ \\
\hline 8 & $\begin{array}{l}\text { Making Healthy } \\
\text { Snacks }\end{array}$ & $\begin{array}{l}\text { Reciprocal determinism: engage family } \\
\text { members in the creation of healthy snacks } \\
\text { to encourage changes in food choices in } \\
\text { the home environment }\end{array}$ & $\begin{array}{l}\text { Choose a healthy snack using } \\
\text { information from Nutrition Facts } \\
\text { labels }\end{array}$ & $\begin{array}{l}\text { Make a healthy snack using } \\
\text { vegetables from the garden }\end{array}$ & $\begin{array}{l}\text { Create a recipe for a healthy } \\
\text { snack with family members } \\
\text { Set goals to make healthy } \\
\text { snacks }\end{array}$ \\
\hline
\end{tabular}


Table 3. Selected Examples of Observations and Revisions Made to Discovering Healthy Choices as a Result of Pilot Testing Phases 1 and 2

\begin{tabular}{|c|c|c|c|c|}
\hline \multirow{3}{*}{$\begin{array}{l}\text { Module } \\
1\end{array}$} & \multicolumn{2}{|c|}{ Pilot-Testing Phase 1} & \multicolumn{2}{|c|}{ Pilot-Testing Phase 2} \\
\hline & Observation & Subsequent Revision & Observation & Subsequent Revision \\
\hline & $\begin{array}{l}\text { Learning about agriculture around } \\
\text { the world sparked student interest } \\
\text { in cultural foods and traditions }\end{array}$ & $\begin{array}{l}\text { Activities were added to allow } \\
\text { investigation of cultural foods }\end{array}$ & $\begin{array}{l}\text { There were not enough unique } \\
\text { countries for each group of } 3-4 \\
\text { students to explore }\end{array}$ & Additional resources were added \\
\hline 2 & $\begin{array}{l}\text { Students appeared confused } \\
\text { about what they were expected to } \\
\text { do }\end{array}$ & $\begin{array}{l}\text { Prompt was added to the } \\
\text { procedure to provide additional } \\
\text { information }\end{array}$ & $\begin{array}{l}\text { Locatingthe students' pulse was } \\
\text { difficult }\end{array}$ & An illustration was created \\
\hline 4 & $\begin{array}{l}\text { Students needed to convert } \\
\text { between measurements but did } \\
\text { not have a reference of unit } \\
\text { conversions }\end{array}$ & $\begin{array}{l}\text { Resource for unit conversions } \\
\text { was added }\end{array}$ & $\begin{array}{l}\text { Measuring foods required extra } \\
\text { clean-up }\end{array}$ & $\begin{array}{l}\text { Garbage bags were added as a } \\
\text { required material }\end{array}$ \\
\hline 5 & $\begin{array}{l}\text { Students had difficulty } \\
\text { understanding that MyPlate } \\
\text { recommendations were for the } \\
\text { entire day and not just one meal }\end{array}$ & $\begin{array}{l}\text { Handout and instructions were } \\
\text { amended }\end{array}$ & $\begin{array}{l}\text { Students found it difficult to } \\
\text { complete the activity due to lack } \\
\text { of reference to MyPlate }\end{array}$ & $\begin{array}{l}\text { The MyPlate icon was added as } \\
\text { handout }\end{array}$ \\
\hline 8 & $\begin{array}{l}\text { Student groups were tested with } \\
4-5 \text { in each group; groups with } \\
\text { five students were not suitable for } \\
\text { effective implementation }\end{array}$ & $\begin{array}{l}\text { Student groups were set to 3-4 } \\
\text { students }\end{array}$ & $\begin{array}{l}\text { Students used prior knowledge } \\
\text { gained in Module } 6 \text { about food } \\
\text { labels in order to determine what } \\
\text { ingredients to put in their salads }\end{array}$ & $\begin{array}{l}\text { Prompt was included to } \\
\text { encourage educators to provide } \\
\text { examples of food packaging to } \\
\text { encourage investigation }\end{array}$ \\
\hline
\end{tabular}


Figure. Process Used to Develop and Pilot-Test Discovering Healthy Choices for the Shaping Healthy Choices Program (SHCP)

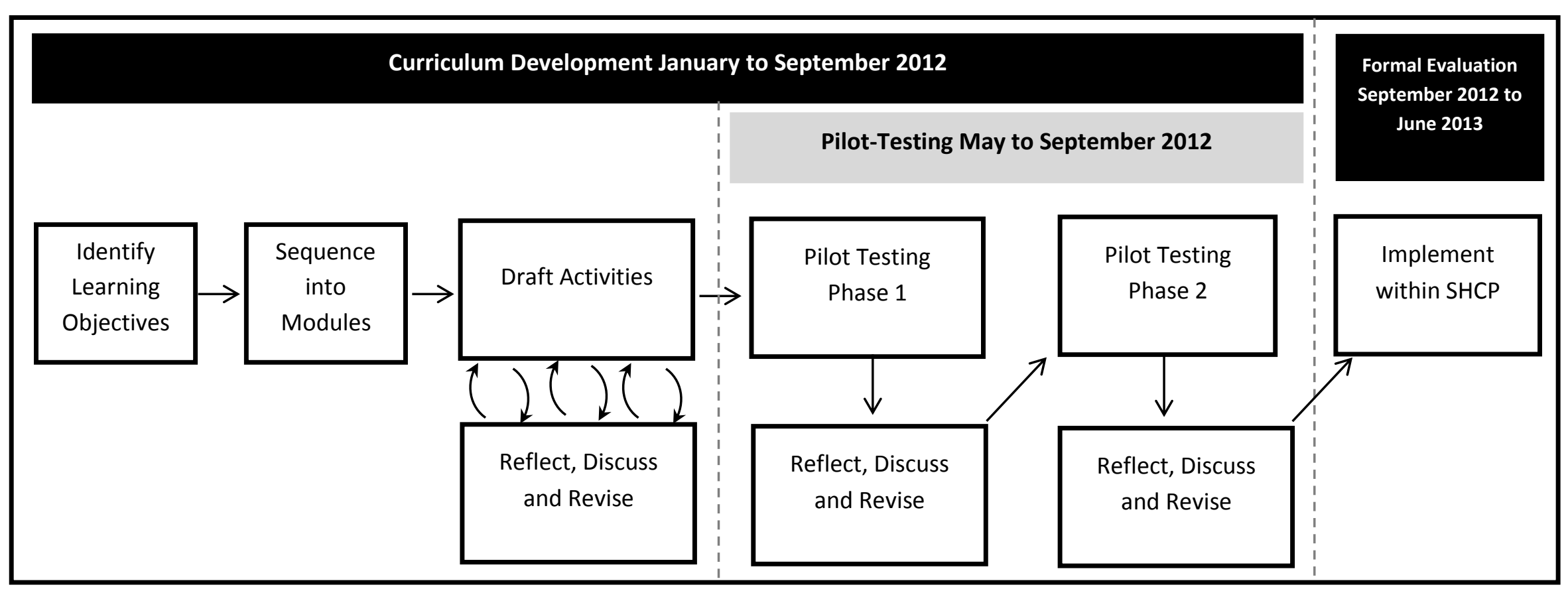

